\title{
PEPPERDINE
}

UNIVERSITY — Pepperdine Dispute Resolution Law Journal

2-1-2005

\section{Cutting the Cord: Ho'oponopono and Hawaiian Restorative Justice in the Criminal Law Context}

Andrew J. Hosmanek

Follow this and additional works at: https://digitalcommons.pepperdine.edu/drlj

Part of the Criminal Law Commons, Criminal Procedure Commons, Dispute Resolution and Arbitration Commons, Law and Psychology Commons, Law and Society Commons, and the Other Law Commons

\section{Recommended Citation}

Andrew J. Hosmanek, Cutting the Cord: Ho'oponopono and Hawaiian Restorative Justice in the Criminal Law Context , 5 Pepp. Disp. Resol. L.J. Iss. 2 (2005)

Available at: https://digitalcommons.pepperdine.edu/drlj/vol5/iss2/6

This Article is brought to you for free and open access by the Caruso School of Law at Pepperdine Digital Commons. It has been accepted for inclusion in Pepperdine Dispute Resolution Law Journal by an authorized editor of Pepperdine Digital Commons. For more information, please contact bailey.berry@pepperdine.edu. 


\title{
Cutting The Cord: Ho'oponopono And Hawaiian Restorative Justice In The Criminal Law Context
}

\author{
Andrew J. Hosmanek ${ }^{1}$
}

\section{INTRODUCTION}

Ho'oponopono is a traditional Hawaiian dispute resolution system that has recently experienced a resurgence of interest. The word ho'oponopono literally means "to make right." In this system, both the offender and victim participate in a type of guided mediation along with other stakeholders in the offense. Ho'oponopono is different from typical mediations because after the session is successfully completed, the participants figuratively cut the "cord" of legal and psychological entanglement that binds them; in other words, the dispute is put to rest forever. When victim and offender come to a true resolution of the problem, and jointly make the decision to move forward without further conflict on the issue, true healing can occur.

Recent interest has focused on using ho'oponopono in family law disputes, but the topic of this article will be the potential applications of ho'oponopono in the criminal law context. In Part II I will provide a brief history of ho'oponopono and explain its methods. In Part III I will describe current uses of ho'oponopono. Last, in Part IV I will propose a general plan for using ho'oponopono in the criminal law setting.

\section{HISTORY OF HO'OPONOPONO}

To understand ho'oponopono, one must understand a bit about the Hawaiian Islands and their history. What we now call "Hawaii" is a chain of approxi-

1. Associate, Fischer Law Firm LLP, Vinton, Iowa (www.fishlawusa.com). JD/MBA 2005, The University of Iowa College of Law and Henry B. Tippie School of Management. B.B.A. University of Iowa College of Business, 2001. Email: andrewhosmanek@gmail.com. Mahalo to the Board of the Native Hawaiian Bar Association, especially the Hon. Melvin K. Soong, Ms. Mona Bernadino, and Ms. Yuklin Aluli for their input. Special thanks also to Professors Nancy Hauserman and Lon Moeller of the University of lowa College of Business for their constant support and inspiration. Mahalo nui loa!

2. Manu Meyer, To Set Right - Ho'oponopono, A Native Hawaiian Way of Peacemaking, The Compleat Lawyer 30, Fall 1995. 
mately 132 islands stretching about 1500 miles on the Hawaiian Ridge, an undersea fault line. ${ }^{3}$ These islands were all formed by volcanoes. ${ }^{4}$ Eight of the islands are currently inhabited. The islands were probably first reached by voyagers from the Marquesas Islands around 600-700 AD. ${ }^{5}$ The Hawaiian islands were further settled by people from the Society Islands around $1100 \mathrm{AD}^{6}$ The islands are "the most isolated inhabited pieces of land in the world,"7 and their culture evolved from 1100 on with relatively little interference from outside sources. Many sources credit Captain James Cook's landing on the Big Island (the island of Hawaii) in 1778 as the first Western contact with the islands. ${ }^{8}$ Prior to Westernization, Hawaii had a geographically dispersed variety of monarchies, all with a strict caste system. ${ }^{9}$ At the top of each was the king, followed by the ali' $i$, or ruling-class chiefs, the kahuna, or priests, and the commoners. ${ }^{10}$ The various kingdoms were united in 1810 by Kamehameha the Great. " Hawaii was increasingly visited by Westerners, most frequently the Americans. Many Christian missionaries came to Hawaii, starting around $1820 .^{12}$ They converted many thousands of Hawaiians to Christianity, eliminating many traditional religious practices. In 1893 the Kingdom of Hawaii was "overthrown by force" by the American provisional government, and Hawaii was annexed by the United States in $1898 .^{13}$ In 1959 , Hawaii became the $50^{\text {th }}$ state. $^{14}$

The history of Hawaii is thus characterized as extremely long periods of isolation and cultural development followed by sudden radical change. In spite of the rapid changes of the $19^{\text {th }}$ century, native Hawaiians have retained a very strong cultural identity and sense of aloha, ${ }^{15}$ which is important in understand-

3. Only in Hawaii: Islands Unique in all the World, available at: http://gohawaii.about.com/cs/onlyinhawaii/a/only_in_hawaiia.htm (last visited December 14, 2004).

4. Id.

5. Hawaii History, available at: http://www.hawaiian-roots.com/hawaiihistory.htm (last visited December 14, 2004).

6. Id.

7. Only in Hawaii: Islands Unique in all the World, available at: http://gohawaii.about.com/cs/onlyinhawaii/a/only_in_hawaiia.htm (last visited December 14, 2004).

8. Hawaii History, available at: http://www.hawaiian-roots.com/hawaihistory.htm (last visited December 14, 2004).

9. Id.

10. Id.

11. Id.

12. Missionaries, available at: http:/www.hawaiian-roots.com/missionaries.htm (last visited December 14, 2004).

13. Id.

14. Hawaii History, available at: http://www.hawaiian-roots.com/timeline.htm (last visited December 14, 2004).

15. Aloha is defined as: love, affection, compassion, mercy, sympathy, pity, kindness, sentiment, grace, charity; greeting, salutation, regards; sweetheart, lover, loved one; beloved, loving, kind, compassionate, charitable, lovable; to love, be fond of; to show kindness, mercy, pity, charity, affection; to venerate; to remember with affection; to greet, hail. (www.wehewehe.org, last visited 
[Vol. 5: 2, 2005]

PEPPERDINE DISPUTE RESOLUTION LAW JOURNAL

ing the ho'oponopono process. Hawaii was (and to a large extent, still is) a geographically isolated culture with a strong spirit of peace and unity. It is natural that a restorative justice system such as ho'oponopono would flourish in this setting. Hawaiians had significant geographical barriers to leaving the relatively small islands, and thus would see each other regularly no matter what had occurred (in essence, all citizens were "repeat players" in the Hawaiian legal system). Hawaiians thus had a strong desire to make future encounters harmonious, because they wanted peace on their islands and in their families.

Traditionally, ho'oponopono was practiced only within the ohana ${ }^{16}$ or extended family. ${ }^{17}$ Thus, much of ho'oponopono's importance stems from the fact that "[ $[$ ]he extended family in Hawaiian culture is the center of life."18 Ho'oponopono is also a natural fit for Hawaiian culture because many Hawaiians have "a profound belief in a universe that operates on principles of harmonious relationships [between the God(s), nature and man]."19

Ho'oponopono had its origins long before European contact with Hawaii. ${ }^{20}$ However, it had fallen into disuse by the mid-1900's, in part because of the penetration of Christian belief systems which rejected traditional Hawaiian religious practices. ${ }^{21}$ It survived in informal usage among Hawaiian families, and eventually took different forms that often integrated Christian beliefs rather than

December 14, 2004). Aloha is popularly used in Hawaii both as a greeting and to say goodbye. The aloha spirit or state of mind prevalent in Hawaii is one of kindness, peace, and acceptance.

16. Meyer, supra note 2, at 30.

17. 'Ohana is the Hawaiian word for this concept of extended family. 'Ohana is a composite of the words 'oha (taro) and na, which is the plural designation. E. Victoria Shook, Ho'oponopono: Contemporary Uses of a Hawaiian Problem-Solving Process 4 (Honolulu: University of Hawaii) (1985). Taro is a starchy root that is a staple food of many Hawaiians and has been for many years. A Hawaiian legend about the origin of the human race states that Father Heaven (Wakea) slept with his youngest daughter, the Daughter of Earth, and their first child Haloa was born premature and stillborn in the shape of a taro root. The child was buried at the comer of their house, and their second child, also named Haloa, was born healthy as the first human. He "was to respect and to look after his older brother for ever more. In return, the elder Haloa, the root of life, would always sustain and nourish him and his descendants." Thus, taro predates mankind and is considered by many to be sacred to this day. (See http://www.coffeetimes.com/taro.htm, last visited October 28, 2004).

18. Shook, supra note 17.

19. Id. at 6 .

20. Id. at 7 .

21. Id. 
the traditional Hawaiian gods. ${ }^{22}$ The present-day incarnation of ho'oponopono was primarily a result of the efforts of $T \bar{u} t \bar{u}^{23}$ Mary Kawena Pukui.

Pukui was approached by a young social worker at the Queen Liliuokalani Children's Center who had a particularly difficult case involving a juvenile delinquent. ${ }^{24} \mathrm{He}$ wished to solve it the "Hawaiian way" because there were numerous cultural issues at play which seven previous social agencies had been unable to overcome. Pukui began to meet weekly with a psychiatrist, a psychologist, and social workers, forming a "Culture Committee" within the QCLC. ${ }^{25}$ After seven years of meeting in committee, Pukui and the QCLC published a book, $N \bar{a} n \bar{a} I K e K u m u$, and sponsored a project regarding the use of ho'oponopono in the Hawaiian family setting (Ho'oponopono Project II). ${ }^{26}$ These two sources were the primary basis for the research in the work that brought notice of ho'oponopono to the legal community through E. Victoria Shook's Ho'oponopono: Contemporary Uses of a Hawaiian Problem-Solving Process.

There are four classical justifications for punishment in the American legal system: retribution, incapacitation, deterrence and rehabilitation. ${ }^{27}$ The current American justice paradigm focuses on retribution and, to a lesser extent, incapacitation. ${ }^{28}$ This is possible in part because "urban societies are mobile [and] "exits' are easier [in large, mobile societies when] conflicts are unresolved.",29 Ho'oponopono fits more into the category of rehabilitation without falling victim to the pitfalls of the "restorative justice" movement. ${ }^{30}$ Rehabilitation and reintegration were (and are) primary concerns of the Hawaiian people because people in island societies were the ultimate "repeat players" and needed har-

22. Id. at 8 . "One such practice that incorporated Christian values was opening the Bible and pointing to a passage that might give insight and guidance to a troubled individual or group."

23. Tütü is "an affectionate and respectful name for an older person that loosely means 'grandma' or 'grandpa." Id. at 9.

24. Id. at 8 .

25. Id.

26. Id. at 10 .

27. The use of the phrase "American legal system" as opposed to or differentiated from the Hawaiian legal system is not intended as an offense to Hawaiian-Americans. While many Hawaiian-Americans are very proud of Hawaii's status as the $50^{\text {th }}$ state, there are also a large number of pro-Hawaiian sovereignty advocates who resent what they perceive as America's colonization of the former Kingdom of Hawaii. This debate is beyond the scope of this article. Thus, when referring to "Hawaiian" legal systems, I am speaking about traditional practices which trace their roots to the pre-European contact era, and I am purposely avoiding entering the sovereignty debate.

28. The basic consensus of today's scholars is that the United States follows a retributive/incapacitative model after deciding in the $20^{\text {th }}$ century that rehabilitation was ineffective. See generally, James M. Byrne, Faye S. Taxman, Targeting for Reentry: Inclusion/Exclusion Criteria Across Eight Model Programs, 68 Federal Probation 53 (September 2004).

29. Meyer, supra note 2, at 32.

30. Restorative justice is often criticized as being ineffective and unfair to victims. See generally, Stephen P Garvey, Restorative Justice, Punishment, and Atonement, 2003 Utah L. Rev. 303. 
mony within their relatively small geographic areas. ${ }^{31}$ Thus, a retributive system which stigmatizes offenders and impairs their future chances of meaningful social interaction is harmful to an island society as a whole. ${ }^{32}$ Ho'oponopono recognizes that "conflict is disruptive to harmonious relationships," views the self as relational, and focuses on the "effects of individual behavior on the group." 33

Ho'oponopono more appropriately recognizes stakeholder concerns in the criminal law context by requiring a full and honest confession from the offender and input from all those affected by the offense. The only similar concept in widespread use in traditional American criminal law is the "victim impact statement." These statements are often ineffective and unsatisfying for all parties concerned. ${ }^{34}$

A ho'oponopono session requires the help and direction of a haku, or facilitator. $^{35}$ Traditionally, this was "a male member of the healing, professional class, known as the kahuna." 36 In contemporary ho'oponopono sessions, the haku is a "respected elder - male or female - who [is] not involved in the issues that have given rise to the ho' oponopono." ${ }^{37}$

The ho'oponopono session begins with the haku saying a pule, or opening prayer. ${ }^{38}$ The prayer is directed toward the Christian God, or perhaps to the aumakua, ${ }^{39}$ asking for "assistance and blessing in the problem-solving en-

31. Meyer, supra note 2, at 32.

32. It is worth noting that most contemporary law review articles which reference ho'oponopono cite the article Ho'oponopono: Some Lessons From Hawaiian Mediation, 11 Negotiation J. 52 (1995), written by James A. Wall, Jr. and Ronda Roberts Callister. This article posits that ho'oponopono arose from the Hawaiians' "oral, rather than written tradition" and their reliance on "superstitions." It is my opinion that the tone of the article is condescending and dismissive, and that much of the article is factually flawed. Those readers wishing to do further research on ho'oponopono would do better to consult the E.V. Shook monograph or the Manu Meyer article, supra.

33. Meyer, supra note 2, at 32.

34. "Victims usually sit with the public behind the defendant while the judge evaluates the defendant's words and demeanor. At most, they read brief victim-impact statements or, more commonly, submit written statements before sentencing, which judges rarely read aloud. There is no victim-offender dialogue and no opportunity for face-to-face apology or expressions of contrition." Stephanos Bibas and Richard A. Bierschbach, Integrating Remorse and Apology into Criminal Procedure, 114 Yale L.J. 85 (October 2004) (internal citations omitted).

35. Meyer, supra note 2, at 31 .

36. Id.

37. Id.

38. Shook, supra note 17 , at 11.

39. 'Aumakua are: "Family or personal gods, deified ancestors who might assume the shape of sharks, owls, hawks, mudhens, octopuses, eels, mice, rats, dogs, caterpillars, rocks, cowries, clouds, or plants. A symbiotic relationship existed; mortals did not harm or eat aumākua, and aumākua 
deavor." 40 The prayer is a necessary part of the ho'oponopono, as it "lays the foundation for sincerity and truthfulness." eral problem. This step is called kükulu kumuhana. ${ }^{42}$ This phrase has the additional meaning of "the pooling of strengths for a shared purpose" and also can refer to "the leader's effort to reach out to a person who is resisting the ho'oponopono process to enable that person to participate fully." 43 The procedures to be followed in the session are put forth during this phase.

Next, the haku brings the specific problem to the forefront. The problem is known as the hala, or transgression. Hala is also the name of the screw pine tree, or pandanus." This tree has "long, stilt-like roots that weave loosely around each other like wicker." 45 Thus, the term hala used in the setting of ho'oponopono means not only wrongdoing but also entanglement. The hala relationship "implies that the perpetrator and the person wronged are bound together." This "relationship of negative entanglement" is known as hihia, which can also mean fishnet or knot. ${ }^{47}$ The current American justice system, even though it is not victim-focused, binds the victim and offender in so many ways. First and foremost, the entire procedure of determining guilt and punishment, from arrest to adjudication, is incredibly lengthy for many crimes. Statistics from 1981 placed the average trial delay for federal crimes at around six months, which is actually an improvement over the earlier part of the $20^{\text {th }}$ century. ${ }^{48}$ Additionally, the average sentence in the federal criminal system is 44.7 months for white defendants, and 68.5 months for black defendants. ${ }^{49}$ Thus, in many cases the criminal does not fully repay his debt caused by the injury for many months or years, and the offender and victim remain entangled because of

warned and reprimanded mortals in dreams, visions, and calls." See generally, http://www.coffeetimes.com/aumakua.htm and http://www.wehewehe.org (last visited December 14, 2004). Originally ho'oponopono prayers were directed toward the ancestral gods, but Christian missionaries caused the Hawaiians to abandon their traditional religious beliefs, including the ancestral gods. Thus, those Hawaiians who were converted to Christianity typically substituted prayer to the Christian God for prayers to the 'aumakua.

40. Shook, supra note 17 , at 11 .

41. Id. Since the ho'oponopono process entails reconciliation of man with "family, nature and God" the prayer is very necessary to the process. See Kim Steuterman Rogers, Sacred Harmony, Hawaii Magazine 33, 34 (January/February 2004).

42. Shook, supra note 17 , at 11 .

43. Id.

44. Rogers, supra note 41 , at 33 .

45. Id.

46. Shook, supra note 17 , at 11 .

47. Rogers, supra note 41 , at 33-34, Shook, supra note 17, at 11 . Interestingly, hihia also translates to "case" or "court case" according to many Hawaiian dictionaries. See http://wehewehe.org (Last visited November 8, 2004).

48. David S. Clark, Adjudication to Administration, A Statistical Analysis of Federal District Courts in the Twentieth Century, 55 S. Cal. L. Rev. 65, Figure 4 (1981).

49. Erwin Chemerinsky, Evolving Standards of Decency in 2003-Is the Death Penalty on Life Support? 29 U. Dayton L. Rev. 201, 206 (2004). 
[Vol. 5: 2, 2005]

PEPPERDINE DISPUTE RESOLUTION LAW JOURNAL

the wrongdoing. Our criminal justice system also keeps the victim and offender bound together by never allowing an opportunity for them to be unbound. ${ }^{50}$

Most ho'oponopono sessions address more than the immediately apparent transgression in order to get to the heart of the matter. Especially in a family setting, "the initial hurt is often followed by other reactions, further misunderstandings, and so forth until a complex knot of difficulties has evolved."51 The $h a k u$ helps the participants work out the problems through mahiki, which is a systematic discussion of the problems, layer by layer. ${ }^{52}$ This is often analogized to peeling an onion. As the participants discuss each problem, it is peeled away, revealing another problem beneath the first. ${ }^{53}$ The actors involved "keep going around the circle, one layer at a time, until [they] get to the root problem." 54

Contrary to typical mainland mediation, there is no "cross-talk" between victim and offender during this stage. In fact, all discussion "is led and channeled by the leader." ${ }^{55}$ Cross-talk at this stage of the session could cause tempers to flare and the ho'oponopono to fail. Hawaiians traditionally felt that "allowing emotional expressions to escalate discouraged problem resolution." 56

Everyone "who has been affected by the problem in some way- directly or indirectly-is asked to share his or her feelings, or mana'o."57 This is in stark contrast to the mainland's adversarial justice system which focuses on "the state" 58 as the injured party and generally does not give the offender or victim a

50. I will discuss this assertion further in the sections on victim impact statements and acceptance of responsibility. Basically, our current system does not require the offender to make a meaningful apology to the victim. By taking the victim out of the process, the cord of entanglement is never cut.

51. Shook, supra note 17 , at 11.

52. Id.

53. Rogers, supra note 41 , at 34 .

54. Id.

55. Shook, supra note 17 , at 11.

56. Id. Cross-talk is a very important part of many mainland-America mediations. However, in addition to the reasoning above, cross-talk is inapplicable to ho'oponopono because it situates the victim and offender on equal footing and may encourage competitive behavior. The offender is there to apologize and make right, and this process can only be facilitated through the unquestioned authority of the haku. Allowing the offender to address the victim directly implicates concems about intimidation. Additionally, if face-to-face discussion between victim and offender were a viable option, a ho'oponopono session would probably not be necessary.

57. Shook, supra note 17, at 12. Mana'o is defined more as intellectual thought ("belief, opinion, theory, thesis, intention") than emotional feelings. See http://wehewehe.org (Last visited November 8, 2004).

58. Mainland case citations are in the form United States v. Offender or State v. Offender. This simple bit of semantics implicitly (albeit unintentionally) excludes consideration of harm done to the victim. 
voice, let alone other parties affected by the transgression. ${ }^{59}$ The haku encourages participants to share "honestly, openly, and in a way that avoids blame and recrimination." 60 If tempers flare, the haku will declare ho'omalu, "a coolingoff period of silence." 61 This period of silence "enables the family to reflect once again on the purpose of the process and to bring their aroused emotions under control."62

After the discussion, it is time for mihi. ${ }^{63} \mathrm{Mihi}$ is "the sincere confession of wrongdoing and the seeking of forgiveness." 64 In ho'oponopono, "it is expected that forgiveness be given whenever asked. ${ }^{65}$ If restitution is necessary then the terms of it are arranged and agreed upon [by the victim and offender]."66

After mihi, the participants move to kala, or the "cutting of the cord." 67 Kala is especially important and unique. The "cord" that is cut here is the figurative cord of the offense that binds both offender and victim. This is expressed by the phrase "Ke kala aku nei'au ia 'oe a pela noho'l 'au e kala ia mai ai" or

59. Recognizing the state, and its citizens therein, as the named victims of crimes and prosecuting accordingly would seem to include the actual victim and all other stakeholders. In practice, many victims feel very disenfranchised by their lack of input in the criminal process. This has led to the "Victim's Rights Movement." See generally, Elizabeth Beck, Brenda Sims Blackwell, Pamela Blume Leonard and Michael Mears, Seeking Sanctuary: Interviews with Family Members of Capital Defendants, 88 Comell L. Rev. 382 (2003). In an island society such as Hawaii, excluding victims from the process and ignoring reintegration leads to problems because the offenders will invariably interact with their victims even after release from incarceration.

60. Shook, supra note 17 , at 12.

61. Id.

62. Id.

63. Id.

64. Id.

65. While it is expected that forgiveness be granted, this expectation only arises after successful ho'oponopono sessions. As discussed later in this section, the victim is not required to grant forgiveness if the offender will not cooperate fully or if the problem runs too deep.

66. Id. This is an interesting contrast to Professor Garvey's oft-quoted restorative justice theory of atonement. His atonement theory involves performing the restitution before asking forgiveness ("expiation") and provides an out for an offender who cannot get forgiveness from his victim. ("Likewise, if the victim cannot find his way to try to forgive, even after the offender has done all he can to earn forgiveness, then the community, speaking through some formal process of public authority, must be prepared to step in. While the community cannot give the victim's forgiveness--only the victim can give that-- it can and should express its own conviction, perhaps through an official 'reintegration ceremony,' that the community is prepared to grant the offender readmission, even if the victim is not.") Stephen P Garvey, Restorative Justice, Punishment, and Atonement, 2003 Utah L. Rev. 303. This seems to be a subtle departure from Professor Garvey's earlier take on atonement and reconciliation, in which he stated, "It reflects a moral failure, however, for victims to withhold forgiveness unreasonably from offenders who have done all they can do to expiate their guilt." Stephen P. Garvey, Punishment as Atonement, 46 UCLA L. Rev. 1801, 1828 (1999). Professor Garvey's earlier position is more in line with ho'oponopono, as to allow the other participants to "pardon" the offender when the victim is unwilling would be a direct contradiction to ho'oponopono's ideals.

67. Kala translates as "To loosen, untie, free, release, remove, unburden, absolve, let go, acquit, take off, undo." See http://wehewehe.org (Last visited November 8, 2004). 
[Vol. 5: 2, 2005]

PEPPERDINE DISPUTE RESOLUTION LAW JOURNAL

"I unbind you from the fault, and thus may I also be unbound by it." Both offender and victim must agree to move forward, and once the cord is cut, the incident and all the bad feelings are put to rest, forever. Generally, the incident is not brought up again. However, it is not accurate to say the incident has been forgotten or repressed. If the incident is remembered, "it will be remembered as 'no big thing anymore." 68

The final phase of ho'oponopono includes pani, a "summary of what has taken place and, importantly, a reaffirmation of the family's strengths and enduring bonds. ${ }^{, 69}$ There is then a closing prayer, or pule ho'opau, ${ }^{70}$ and a closing meal or snack to which all the participants have contributed.

Ho'oponopono may take many sessions to complete. There is no rigid time frame, and it is not considered successful if the participants don't feel comfortable moving to the next stage. Ho'oponopono is not always successful in reintegrating the offender. If a family member refuses to participate in the ho'oponopono process, or refuses "to embrace the family with any sense of aloha," the family may exercise the option of mo ka piko, which means "to sever the umbilical cord." In this case, the person may be cast out of the family forever.

\section{CURRENT USES OF HO'OPONOPONO}

The Native Hawaiian Bar Association (NHBA) ${ }^{72}$ "is an association of lawyers, judges and other legal professionals of Hawaiian ancestry which seeks to promote unity, cooperation and the exchange of ideas among its members." The NHBA is "in the process of developing a Ho'oponopono Program to provide an alternative culturally sensitive means of resolving legal disputes." This project, known as the Ho'oponopono Project, is coordinated by retired Judge and NHBA President Melvin Soong.

The NHBA will be referred proper cases by Family Court or Hawaiian organizations that feel a cultural resolution of the matter is desired and is applicable. NHBA will administer the program, train the Hakus, and maintain overall control of the project. If the Courts are involved, the Haku's and parties

68. Meyer, supra note 2, at 35 .

69. Shook, supra note 17 , at 12 .

70. Id.

71. Meyer, supra note 2, at 34 .

72. See www.hawaiianbar.org (Last visited November 9, 2004).

73. Id.

74. See www.hawaiianbar.org/articles.html (Last visited November 9, 2004). 
report back to the Courts. The program is strictly voluntary and can be terminated by any of the parties at anytime. The goals of the project are to use culturally derived practices to resolve differences between the parties. It is perceived as an alternate to court or other formal type of proceedings. ${ }^{75}$

The process will first be used in family court, civil, or private disputes, but members of the NHBA haven't closed the door to criminal applications. However, criminal law use, if it is implemented, would occur after the ho'oponopono system was up and running in the family court system. Mona Bernadino, a board member of NHBA, stated that using ho'oponopono in criminal cases "would be well down the road, probably at least a couple years, after we have a smooth-running, effective system with Family Law cases. Applying ho'oponopono in criminal situations will require the cooperation of the prosecutor's office and victim/witness programs."

The Ho'oponopono Project seems to be at the forefront of ho'oponopono in practice today. Another Hawaiian group, the Legal Aid Society of Hawaii, ${ }^{76}$ was granted $\$ 250,000$ by the United States Department of Justice in 2001 to apply ho'oponopono in family law situations. This project was known as the Navigator Project. ${ }^{77}$ However, there is no mention of the Navigator Project on the Society's website, and inquiries about the program went unanswered.

Anecdotally, various family law organizations use ho'oponopono in family law, family mediation, and battered spouse situations. ${ }^{78}$ Ho'oponopono is also, of course, still used in some traditional Hawaiian families to settle family disputes. Although common practice has traditionally restricted ho'oponopono to family disputes and family law, and indeed, ho'oponopono seems ideally suited for these situations, ho'oponopono has potential applications beyond family matters. $^{79}$ Ho'oponopono has a number of potential applications in the criminal law context.

75. Email interview with The Hon. Melvin Soong, retired Circuit Court Judge and President of the Native Hawaiian Bar Association, October 4, 2004.

76. See http://www.legalaidhawaii.org (Last visited November 9, 2004).

77. Kim Steuterman Rogers, Sacred Harmony, Hawaii Magazine 33, 35-36 (January/February 2004).

78. For instance, Hawaii's Child Protective Services (under the Department of Health and Human Services) will provide ho'oponopono services in family disputes. However, they require additional dispute resolution because they feel ho'oponopono cannot work properly where there has been domestic abuse or violence. Efforts by Child Welfare Agencies to Address Domestic Violence, available at: http://www.urban.org/url.cfm?ID=406798 (last visited December 14, 2004).

79. While it is very hard to find data on the practice of ho'oponopono, it seems at present to be used mainly in parallel to, or instead of, Hawaii's state court system and dispute resolution mechanisms. Although the abovementioned grant for the Navigator Project would imply a use of ho'oponopono within the state court system, I could find no evidence the Navigator Project was ever implemented. 


\section{A PROPOSAL FOR APPLYING Ho'OPONOPONO IN CRIMINAL LAW}

\section{A. Ho'oponopono Can Serve as an Effective Diversion Program for Misde- meanors}

Current American misdemeanor prosecution practices are faulty as applied. The stigma associated with a criminal conviction is disproportionate to the harm done to society by certain offenses, especially considering the collateral consequences of conviction. For instance, a student with a "minor" theft conviction might be foreclosed from career paths in finance, law enforcement or national security many years later. The availability of public records on the internet has made it much easier for employers to take this sort of information into account. The only real alternatives provided other than the straightforward prosecution of minor offenses are seeking a deferred adjudication, asking the prosecutor to drop the charges, or charge bargaining down. ${ }^{80}$

Existing diversionary programs such as drug court or court-ordered anger management go more toward the problems of the offender rather than the hurt caused to society and the victims. Ho'oponopono would be a workable diversion program for misdemeanor offenses such as minor theft, assault and crimes against property. It is uniquely suited to these types of crimes because there is a well-defined victim as well as an injury to society. It is, however, also a workable diversion solution for certain "victimless" crimes or crimes without welldefined victims.

As mentioned above, our current justice system follows the retributive, or "just deserts" ideal, with a dose of incapacitation thrown in. ${ }^{81}$ This ideal is critically flawed for a number of reasons: it does not address restitution, it is not restorative, and it unfairly stigmatizes offenders.

Currently, restitution in the context of a misdemeanor crime consists mainly of a court-ordered monetary payment. Upon conviction, the offender often receives a sort of invoice with a dollar amount payable to the court at the same time as the fines and court costs due. The court then disburses the money to the victim. Implicitly, this looks more like a punishment than true restitution. The money is paid to the court, not the victim, and once again the victim is cut out of the process. Additionally, current procedure generally allows only for money restitution, which is not always adequate to remedy the situation.

80. A charge bargain is one where the prosecutor agrees to charge a lesser offense than he could probably prove on the facts of the case.

81. See generally, James M. Byrne, Faye S. Taxman, Targeting for Reentry: Inclusion/Exclusion Criteria Across Eight Model Programs, 68 Federal Probation 53 (September 2004). 
The retributive ideal is antithetical to the principles of restorative justice, or even reintegration. The point of retribution is to get revenge, or inflict a like injury on the accused. In a pure sense, this is not revenge with the idea of creating an example or deterring others from committing similar crimes; it is simply the idea that society has the right or obligation to inflict an injury equal to that inflicted by the offender. Retributivism is characterized by the eye-for-an-eye, or "just deserts" model, where a criminal is given an individualized punishment according to the badness of his act. Retributive "justice" fails because it ignores the future - it glibly inflicts punishment and stigma on the offender without thought to resultant harm to society. A justice system that is obsessed with adjudicating fault without an eye toward reconciliation and reintegration is not workable in an island culture, and ho'oponopono's reintegrative component is one of its greatest strengths. As Judge Melvin Soong states, "[One] of the goals of Ho'oponopono is not to find fault but more to understand one's position in the conflict and to resolve the conflict so the family [and] community can be one again., 82

Allowing a ho'oponopono session as a form of diversion in minor criminal cases would be workable and result in a number of benefits. In a meta-study of mainland-style criminal/victim mediations, offenders recidivated less often after the offender and victim talked through the particulars of the offense. ${ }^{83}$ It is logical to assume that successful ho'oponopono would also reduce same-offense recidivism and overall recidivism, since a successful ho'oponopono results in the offender realizing the impact of his crime on the community.

As mentioned above, the "best" crimes for ho'oponopono resolution would seem to be those with a well-defined victim, such as theft, assault, or crimes against property. With a well-defined victim, it is easier to gather together all the people affected by the crime for a ho'oponopono session. However, the effects of other crimes, even so-called "victimless crimes," such as drug use, can be ameliorated by ho'oponopono. As Mona Bernadino of the Native Hawaiian Bar Association points out, ho'oponopono could be useful in drug possession cases "in terms of [the] family letting [the] perpetrator know he/she is loved and needs to change if he/she wants the family to be whole," and in drug distribution cases "in terms of community letting [the] perpetrator know he/she is an important part of the community and needs to change in order for the community to be healthy." 84

82. Email interview with The Hon. Melvin Soong, retired Circuit Court Judge and President of the Native Hawaiian Bar Association. October 4, 2004.

83. Stephanos Bibas \& Richard A. Bierschbach, Integrating Remorse and Apology into Criminal Procedure, 114 Yale L.J. 85, 131 (October 2004). This article contains an excellent discussion of Western-style victim-offender mediation that can be easily analogized to ho'oponopono beginning on page 130.

84. Email interview with Mona Bernandino of the Native Hawaiian Bar Association, October 4, 2004. 
The mechanics of the ho'oponopono diversion would require a guilty plea by the defendant prior to the ho'oponopono session. This is necessary as a good-faith effort by the offender to acknowledge his wrongdoing. If a defendant does not confront his guilt, he will be able to rationalize, deny or minimize the guilty act. This stops him from fully taking responsibility for his actions, and prevents him from being fully rehabilitated. ${ }^{85}$

The result of a successful ho'oponopono session would be equivalent to a deferred judgment. There would be in most cases a one year period of probation, and if no additional crimes are committed in this period, the sentencing authority will remove the offense from the offender's record completely. The one-year probation is not antithetical to the hala, or cutting of the cord, in a traditional ho'oponopono because a traditional ho'oponopono might require many sessions spanning many months. ${ }^{86}$ In a sense, the proposed diversionary ho'oponopono would not really be completed until the offender completely serves his probation, and thus fits neatly within the traditional model. Requiring this probationary period would also help allay the fears of those who think an offender could "act" his way through a ho'oponopono session.

For this program to work, it will need the support of prosecutors, judges and victims. Ho'oponopono cannot work without the full cooperation of both victim and offender, so if either are unwilling, the case would have to progress through the adversarial justice system instead. The prosecutor would have to agree to the ho'oponopono diversion program, and there may be an agency problem inherent. ${ }^{87}$

\section{B. Ho'oponopono as a replacement for the victim impact statement/statement of acceptance of responsibility in more serious crimes}

As mentioned above, many people find the current system of victim impact statements to be lacking. In fact, victim impact statements can be one-sided and frequently vindictive. ${ }^{88}$ They serve no purpose other than catharsis for the victim, which is not alone a legitimate goal of our criminal justice system, because

85. Bibas and Bierschbach, supra note 83, at 140.

86. Shook, supra note 17 , at 12 .

87. Prosecutors measure their success through "statistics," including convictions and conviction rate. A defendant who successfully completes probation after a deferred adjudication has the conviction taken off his record. Thus, this would seem to lower a prosecutor's conviction rate. However, prosecutors can probably avoid this agency problem by counting the initial guilty plea in their "statistics."

88. Jayne W. Barnard, Allocution for Victims of Economic Crimes, 77 Notre Dame L. Rev. 39 , $56(2001)$. 
there are more stakeholders in the incident than just the victim. If the victim is allowed to speak, all the stakeholders should be allowed to speak as well (which is one of the benefits of ho'oponopono). Acceptance of responsibility statements ${ }^{89}$ in federal criminal cases is also often meaningless. They frequently consist of a statement written by the defendant's lawyer, read by the defendant to a judge who didn't preside over the trial. ${ }^{90}$

Ho'oponopono sessions would be a better alternative for both victim impact statements and acceptance of responsibility statements. It would promote healing rather than one-sided catharsis, and it would be more meaningful to both offender and victim. The victim would have more of an opportunity to articulate the hurt done by the offender. The offender would have a better opportunity to explain why he committed the offense. By having dialogue rather than monologue, the offender and victim will come to a better understanding of each other.

Under my proposed system, offenders and victims would engage in ho'oponopono sessions post-conviction, but prior to sentencing. This would give the parties time to work out a personalized restitution plan before the sentencing judge imposes prison time or fines.

\section{Incentives to victim and offender to participate in ho'oponopono}

There would be incentives on both sides to use ho'oponopono. The victims would get more closure from the exhaustive ho'oponopono process than they would ever receive from a statement read by either party in court. Also, they could receive more uniquely tailored forms of restitution; mutually agreed-upon solutions that are not limited to money damages. ${ }^{9 !}$

The offenders would also get more closure, and they would have a more meaningful opportunity and venue to pursue reconciliation, presumably leading to less stigmatization and better reintegration. In the case of acceptance of responsibility, ${ }^{92}$ the defendant could make a more compelling case to the sentencing judge for lenity after going through the effort of ho'oponopono and making restitution. Additionally, as mentioned supra, ho'oponopono is the best possible

89. The Federal Sentencing Guidelines provide for downward adjustments for acceptance of responsibility (Section 3E1.1). This discount is often substantial, amounting to a difference of years in the sentence. As currently applied, this adjustment functions practically as an automatic discount for pleading guilty. See generally, Michael M. O'Hear, Remorse, Cooperation, and "Acceptance of Responsibility": The Structure, Implementation, and Reform of Section 3E1.I of the Federal Sentencing Guidelines, 91 Nw. U. L. Rev. 1507 (1997).

90. Id.

91. For example, a vandal could work to repair the damage he did to a house or garden. While some judges already impose penalties of this nature in the current system, the work seems to be punishment in the form of forced labor. A mutually-agreed upon repair job is much more reintegrative, and would hopefully induce the offender to respect property more and not recidivate.

92. If the Federal Sentencing Guidelines survive Blakely, or if an alternate system which incorporates acceptance of responsibility is instituted in their stead. 
solution for an island society full of repeat-players. Successful ho'oponopono should result in less recidivism and same-offense recidivism, which would be attractive to victims and the community as a whole.

A ho'oponopono session would require more effort on both sides from both the victim and offender. In keeping with the principles of ho'oponopono, both sides must be willing participants, and this option would be exercised only with the consent of the victim, offender and judge.

\section{Response to criticisms of ho'oponopono}

Criticisms of ho'oponopono and other alternative dispute resolution schemes based on indigenous or traditional systems tend to run towards two main points: First, that indigenous systems incorporate religion, which is completely incompatible with the American justice system; and second, that indigenous systems are only relevant to the culture in which they developed, and outsiders have no legitimate use for these systems in the modern world. ${ }^{93}$ I will address these points in turn.

Many commentators on traditional dispute resolution systems assume that ho'oponopono would be a better alternative only in cases involving native Hawaiians, but this is not necessarily true. As Ms. Bernadino notes,

In order for ho oponopono to work, there has to be appreciation of Hawaiian culture and values and a desire to incorporate those into the reconciliation process. For example, ho'oponopono incorporates prayer. As long as the parties, whether Hawaiian or non-Hawaiian, understand Hawaiian culture and values and choose to adhere to them, ho'oponopono can work. ${ }^{94}$

Thus, a ho'oponopono diversion project, while necessarily beginning in the Hawaiian Islands due to the availability of qualified hakus and ease of adoption due to a shared cultural background, would be workable in the mainland US as

93. For a vehement discussion of these points, please see Carole E. Goldberg, Overextended Borrowing: Tribal Peacemaking Applied in Non-Indian Disputes, 72 Wash. L.Rev. 1003 (1997).

Cultural differences between Native and non-Indian cultures make the process of crosscultural importation treacherous at best, and altogether futile at worst. This is true even if, as most borrowing proponents assume, alternatives to the prevailing U.S. legal system are desirable, and tribal peacemaking is working well within Indian Country. The operation of tribal peacemaking presupposes certain socio-cultural conditions, such as religious homogeneity and strong kinship networks, that cannot be replicated in most of contemporary non-Indian America.

Id. (Internal citations omitted).

94. Email interview with Mona Bernandino of the Native Hawaiian Bar Association (October 4, 2004). 
well. ${ }^{95}$ The key here is an understanding of the cultural background, and a willingness to work within the ho'oponopono system. It is wrong to say that a nonnative Hawaiian cannot successfully participate in ho'oponopono because of a different cultural background. ${ }^{96}$ If one is a member of the community, whether born or transplanted, ho'oponopono can work because ho'oponopono is community-focused, not racially-focused or ethnically-focused. ${ }^{97}$ In determining the factors that predicted the "effectiveness [of shaming penalties] in norm enforcement," 98 Professor Toni Massaro found:

[E]ffectiveness depends partly on whether a culture shames reintegratively. If the community has rituals to redeem and reclaim the chastened offender afterwards, and shaming is based in part on optimism about her responsiveness to this grooming, then the shaming is reintegrative. The earmarks of reintegrative shame cultures include social cohesiveness, a strong family system, high communitarianism, and social control mechanisms that aim to control by reintegration into the cohesive networks, rather than by formal restraint. ${ }^{99}$

While ho'oponopono is not remotely the same as shaming penalties, it is a reintegrative response to criminal behavior. Hawaiian culture is definitely characterized by "social cohesiveness" and "a strong family system," and the "reintegrative social control mechanisms" can be found implicitly (albeit more poetically) in the spirit of aloha, which calls for peace and harmony among the inhabitants of these relatively small islands. Although the mainland United States is a much larger "island," reintegrative responses can work if there is a strong community, be it geographical, ethnic, or familial. Ho'oponopono might not be a good technique to resolve disputes among total strangers from different states, but it can be effectively used at a local level. Eventually, the use of reintegrative justice could even begin to foster a sense of community through increased trust where this feeling was previously lacking.

95. Judge Soong notes, "As to whether Ho'oponopono would work for mainlanders, we have not projected our plans that far ahead. We are concerned presently [with] starting the project for Hawaiians because this was part of the culture and might be a better way of resolving differences. We may consider Non Hawaiians in the islands who accept and will abide by the procedure ...." Email interview with The Hon. Melvin Soong., retired Circuit Court Judge and President of the Native Hawaiian Bar Association, October 4, 2004.

96. Carole Goldberg's view is that such cultural integration should not even be attempted:

Given the long history of non-Indians romanticizing and essentializing indigenous North American peoples, there is some reason to doubt the accuracy of non-Indian perceptions of tribal justice. Tribal peacemaking has received little systematic empirical study to date. Any such research should be conducted only with the permission of the relevant tribe. Goldberg, supra note 93 , at 1019.

97. Judge Soong notes, "Shared cultural hisory and Ohana are very strong factors in the program. In fact, in past times, it was usually a family friend or a respected person in the community that was the Haku."

98. Toni M. Massaro, Shame, Culture, and American Criminal Law, 89 Mich. L. Rev. 1880, 1924 (1991).

99. Id. 
[Vol. 5: 2, 2005]

PEPPERDINE DISPUTE RESOLUTION LAW JOURNAL

The second argument, that ho'oponopono will not work in mainland justice systems because of its opening and closing prayer, is also false. ${ }^{100}$ As mentioned supra, one of the fundamental tenets of ho'oponopono is that all parties must be willing to work through the entanglement within the guidelines of ho'oponopono. ${ }^{101}$ Everyone must be a willing participant. If the parties agree to ho'oponopono, the state should not interfere simply because it contains a religious component. One of the main reasons ho'oponopono fell into disuse was that Christian missionaries that colonized Hawaii forbade its use because the pule in ho'oponopono were originally directed toward ancestral or traditional Hawaiian gods. Without the prayer component, there exists less incentive for parties to be truthful and make full confessions. ${ }^{102}$ Since no offenders or victims will be compelled by the state to use ho'oponopono, Establishment Clause challenges fail.

\section{CONCLUSION}

Ho'oponopono is a time-honored tradition with current applications. While ho'oponopono is typically applied only in family-law situations at present, it has great potential in the criminal law context. My thesis is not that our current criminal justice system is irretrievably broken, but rather that adding ho'oponopono can reach and heal victims and offenders that have been let down by the current adversarial system. This has been its effect in social work settings, and criminal law is a natural extension. Ho'oponopono can serve as a diversionary program for misdemeanor crimes, and it can replace the victimimpact statement and statement of acceptance of responsibility in more serious crimes. The goals of using ho'oponopono in the criminal setting include reductions in recidivism and same-offense recidivism, and reintegration of offenders. While ho'oponopono grew out of closed island societies with repeat players and

100. Goldberg also mentions this argument:

As Professor Stephen Carter has bemoaned, U.S. legal and political culture formally and practically disavows any penetration of religion into law. The First Amendment's prohibition on the establishment of religion, with its associated insistence on the separation of church and state, provides the official statement of this position.

Goldberg, supra note 93, at 1019, (internal citations omitted).

101. If an offender doesn't believe in God or the traditional gods addressed, ho'oponopono cannot commence. The opening prayer is an integral part that cannot be ignored.

102. Much in the same way, in years past atheists were not allowed to testify in American courts because they could not swear an oath. See generally, Paul W. Kaufman, Disbelieving Nonbelievers, Atheism, Competence, and Credibility in the Turn of the Century American Courtroom, 15 Yale J.L. \& Human. 395 (2003). 
Pepperdine Dispute Resolution Law Journal, Vol. 5, Iss. 2 [2005], Art. 6

a shared cultural background, it can be effectively utilized outside Hawaii. Implementing ho'oponopono as an option in the criminal justice system will lead to better outcomes for victims, offenders, and society as a whole. 